\title{
Unexpected Rupture of Unscarred Uterus at 12 Weeks of Pregnancy: A Case Report and Literature Review
}

\author{
Maryam Vaezi*
}

\begin{abstract}
Objectives: Uterine rupture is an infrequent but serious event in pregnancy, which happens commonly in the second and third trimesters in scarred uteruses and labor phases. Uterine rupture during labor is very rare in the absence of scar and occurs mainly in multiparous women. This article introduces a very unusual case of unexpected rupture of an unscarred uterus in the 12th week of gestation.

Case Presentation: A 34 year old woman with a history of vaginal delivery, gravida 2, para 1, and gestational age of 12 weeks were admitted to Tabriz Taleghani hospital with abdominal pain. With increasing abdominal pain, the patient underwent ultrasound, which showed a lot of abdominal and pelvic free fluid, indicating urgent laparotomy, in which a bleeding rupture of about $5 \mathrm{~cm}$ was found on the posterior wall of the uterus. Placenta and fetus with an intact sac were bulging into the abdomen from the rupture site and hence were excised. The rupture was repaired and the patient was discharged on the third day in good conditions. The patient did not have any risk factors except multiparity.

Conclusion: Regardless of gestational age and history, uterine rupture should be kept in mind for all pregnant women with abdominal pain and signs of peritoneal irritation to timely and quickly detect and manage as a rare but life-threatening condition.

Keywords: Unexpected rupture, Unscarred uterine, Early pregnancy, Case report
\end{abstract}

\section{Introduction}

Uterine rupture is an unusual but serious event in pregnancy. Most cases of uterine rupture occur in the second and third trimesters in the scarred uterus (such as previous caesarean section, hysterotomy or myomectomy) (1). The unscarred uterine rupture is an infrequent condition predisposed by multiparity, malpresentation, use of uterotonic drugs (such as oxytocin or prostaglandins), and connective tissue diseases (2). There are some reports regarding uterine rupture in the absence of labor, without any risk factors (3-9). The chief predisposing factor for unscarred uterine rupture is multiparity (3). On the other hand, unscarred uterine rupture in the absence of labor in the first trimester of pregnancy is a very rare phenomenon on which 3 cases were reported (10-12).

In this paper, a very rare case of unscarred uterine rupture in the first trimester in the absence of labor is presented where multiparity was the only risk factor.

\section{Case Presentation}

A 34 years old female with a history of vaginal delivery, gravida 2, para 1, and gestational age of 12-13 weeks referred to the emergency room of Tabriz Taleghani hospital. Her chief complain was abdominal pain. She was alert and oriented. She had no fever, chills, nausea, vomiting, vaginal bleeding or signs of delivery. She had no history of surgery, curettage, and abortion. Past medical history was negative. On physical examination, vital signs were stable. Abdominal examination revealed mild tenderness in the right lower quadrant, and cervix was normal and closed in gynecological examination. In laboratory tests, $\mathrm{Hb}$ was $10.6 \mathrm{mg} / \mathrm{dL}$ The patient was hospitalized and observed. Ultrasound was performed due to persistence and exacerbation of abdominal pain, and showed the intrauterine gestational sac with a live fetus of 12 weeks and 3 days. The amniotic fluid and adnexa were normal, and a lot of free liquid was seen in abdomen and pelvis which was infiltrated into the splenorenal and Morrison's space. Given the possibility of hemoperitoneum, she underwent urgent laparotomy through a midline incision, and there was about $2 \mathrm{~L}$ of blood in the abdomen and pelvis. A rupture of about $5 \mathrm{~cm}$ was found on the posterior wall of the uterus. Placenta and fetus with intact sac were bulging into the abdomen from the rupture site. There was an active bleeding from uterine rupture. Fetus and placenta were removed completely and the rupture was repaired in three layers of endometrium, myometrium, and perimetrium. The patient received two units of isogroup packed red blood cells and she was discharged on the third day (Figures 1 and 2).

Received 12 February 2017, Accepted 15 May 2017, Available online 1 June 2017

Women's Reproductive Health Research Center, Tabriz University of Medical Sciences, Tabriz Iran.

*Corresponding Author: Maryam Vaezi, Tel: +989144231053, Email: mva260@yahoo.com 


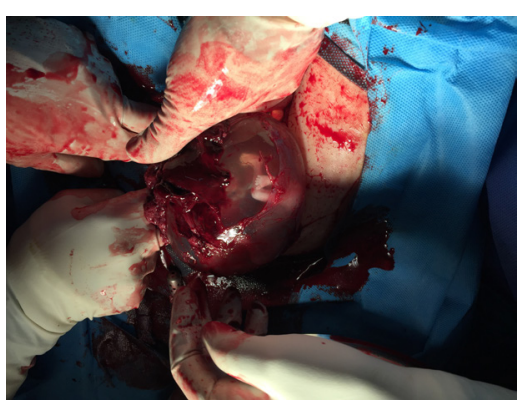

Figure 1. Placenta and fetus with an intact sac were bulging into the abdomen from the rupture site.

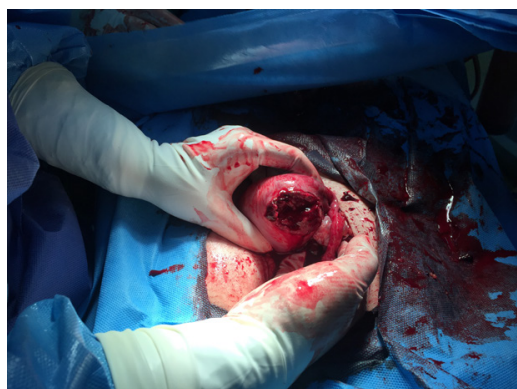

Figure 2. Rupture on the Posterior Wall of the Uterus.

\section{Discussion}

Uterine rupture during pregnancy is an uncommon and unpleasant event. In most cases, it happens in patients with a history of cesarean section, hysterotomy, myomectomy or previous injuries of the uterus (caused by hysteroscopy or curettage). The event happens in the active phase of labor concurrent with labor active contractions, and stimulation of uterine contractions with uterotonic agents (syntocinon or prostaglandins) is the main risk factor. Pregnant uterine rupture is more common during the third trimester when the uterus is further distorted and its wall becomes thinner. The risk of uterine rupture is much lower in unscarred uterus than scarred one. Regarding its incidence, different rates were mentioned in various articles (13). The mean rate is $0.009 \%$ in a period of 20 years (14)

Information in this regard is limited to case reports and few case series. Risk factors include malpresentation, use of oxytocin and prostaglandins, abnormal placenta (previa and accreta), previous invasive mole, multiparity, uterine anomalies, macrosomia, multiple pregnancy, fetopelvic disproportion, and trauma $(1,5)$.

Maternal and fetal morbidity and mortality are significant consequences of uterine rupture. Hysterectomy occurs in 20 to $30 \%$ of the cases of unscarred uterine rupture and perinatal mortality occurs in $12 \%$ to $35 \%$ of the cases $(1,2)$. The severity of the morbidity and the mortality event depends on the timely and quick diagnosis and treatment of this emergency condition. This gains more importance, especially in unscarred uterus and in the absence of labor, particularly in the first and second trimesters, since it is less likely to be diagnosed, leading to later detection and treatment (5).

In this study, we found 8 cases that uterine rupture was occurred in an unscarred uterus at gestational age of below 20 weeks. Patients age range was 28 to 40 years with a mean gestational age of 7 to 17 weeks. In all cases, uterine rupture was occurred spontaneously in the fundus and the patients underwent blood transfusion due to massive hemoperitoneum. Abdominal pain was the chief complaint in all patients, followed by nausea and vomiting due to peritoneal irritation, and dizziness and lethargy. Multiparity was the predisposing factor in 7 out of 8 patients $(88 \%)$. There was a nulliparous case whose risk factor was having been exposed to diethylstilbestrol (DES). Percreta placenta was a risk factor in two cases and uterine anomaly in one case. In terms of treatment, uterine defect was repaired in $50 \%$ of the cases ( 4 cases) and hysterectomy was performed in 3 cases. Maternal outcome was fortunately good in all cases $(5,10-12,15$ 17) (Table 1). Our patient was the fourth case affected at gestational age of 12 weeks or less.

In one case in our study, uterine anomaly risk factor was

Table 1. Uterine Rupture in the Unscarred Uterus at $<20$ Weeks Gestation

\begin{tabular}{|c|c|c|c|c|c|c|c|c|c|}
\hline Author & Year & Age & $\begin{array}{l}\text { Gestational } \\
\text { Age (wk) }\end{array}$ & $\begin{array}{l}\text { Gravid/ } \\
\text { Para }\end{array}$ & $\begin{array}{l}\text { Initial } \\
\text { Presentation }\end{array}$ & Risk Factor & $\begin{array}{l}\text { Rupture } \\
\text { Site }\end{array}$ & Management & Transfusion \\
\hline $\begin{array}{l}\text { Singh and Jain } \\
\text { (15) }\end{array}$ & 2000 & 30 & 8 & G5P3 & Abdominal pain & $\begin{array}{l}\text { Multiparity/ } \\
\text { uterine anomaly }\end{array}$ & Fundus & $\mathrm{TAH}$ & Yes \\
\hline Park et al (12) & 2005 & 36 & 10 & $\mathrm{G} 2 \mathrm{P} 2$ & Abdominal pain & Multiparity & Fundus & Repare & Yes \\
\hline Porcu et al (10) & 2003 & 28 & 12 & G1P0 & Abdominal pain & Exposed DES & Fundus & Unknown & Yes \\
\hline Our case & 2017 & 34 & 12 & G2P1 & Abdominal pain & Multiparity & Fundus & Repare & Yes \\
\hline Esmans et al (11) & 2004 & 40 & 14 & G2P1 & Abdominal pain & $\begin{array}{l}\text { Multiparity/ } \\
\text { placenta percreta }\end{array}$ & Fundus & $\mathrm{TAH}$ & Yes \\
\hline $\begin{array}{l}\text { Mannini et al } \\
\text { (17) }\end{array}$ & 2016 & 34 & 15 & G3P1 Ab1 & Abdominal pain & Multiparity & Fundus & Repare & Yes \\
\hline $\begin{array}{l}\text { LeMaire et al } \\
\text { (16) }\end{array}$ & 2001 & Unknown & 16 & G3P2 & Nausea/vomiting & $\begin{array}{l}\text { Multiparity/ } \\
\text { placenta percreta }\end{array}$ & Fundus & $\mathrm{TAH}$ & Yes \\
\hline Sun et al (5) & 2012 & 31 & 17 & G3P2 & $\begin{array}{l}\text { Abdominal pain/ } \\
\text { nausea }\end{array}$ & Multiparity & Fundus & Repare & Yes \\
\hline
\end{tabular}


caused uterine rupture at a lower gestational age (8 weeks). In addition, exposure to DES had caused uterine rupture in a nulliparous patient, and in 6 other cases including our patient, multiparity was the risk factor.

According to this case report, it can be concluded that regardless of gestational age, history and being a life-threatening complication in all pregnant, uterine rupture should be considered as a differential diagnosis in women who referred due to abdominal pain and signs of peritoneal irritation in order to save the life of mother and fetus as an important indicator of the health in any society.

\section{Ethical Issues}

The author has obtained Informed consent before using patient data and images.

\section{Conflict of Interests}

We hereby declare that there is no conflict of interests.

\section{Financial Support}

None.

\section{References}

1. Gibbins KJ, Weber T, Holmgren CM, Porter TF, Varner MW, Manuck TA. Maternal and fetal morbidity associated with uterine rupture of the unscarred uterus. Am J Obstet Gynecol. 2015;213(3):382.e381-386. doi:10.1016/j. ajog.2015.05.048

2. Miller DA, Goodwin TM, Gherman RB, Paul RH. Intrapartum rupture of the unscarred uterus. Obstet Gynecol. 1997;89(5 Pt 1):671-673.

3. Gurudut KS, Gouda HS, Aramani SC, Patil RH. Spontaneous rupture of unscarred gravid uterus. J Forensic Sci. 2011;56 Suppl 1:S263-265. doi:10.1111/j.1556-4029.2010.01622.x

4. Tarney CM, Whitecar P, Sewell M, Grubish L, Hope E. Rupture of an unscarred uterus in a quadruplet pregnancy. Obstet Gynecol. 2013;121(2 Pt 2):483-485. doi:10.1097/ AOG.0b013e31827c603c.

5. Sun HD, Su WH, Chang WH, Wen L, Huang BS, Wang $\mathrm{PH}$. Rupture of a pregnant unscarred uterus in an early secondary trimester: a case report and brief review. J Obstet Gynaecol Res. 2012;38(2):442-445. doi:10.1111/j.14470756.2011.01723.x.

6. Noh JJ, Park CH, Jo MH, Kwon JY. Rupture of an unscarred uterus in a woman with long-term steroid treatment for systemic lupus erythematosus. Obstet Gynecol. 2013;122(2 Pt 2):472-475. doi:10.1097/AOG.0b013e3182998fb6.

7. Nikolaou M, Kourea HP, Antonopoulos K, Geronatsiou K, Adonakis G, Decavalas G. Spontaneous uterine rupture in a primigravid woman in the early third trimester attributed to adenomyosis: a case report and review of the literature. J Obstet Gynaecol Res. 2013;39(3):727-732. doi:10.1111/ j.1447-0756.2012.02042.x.

8. Matsubara S, Shimada K, Kuwata T, Usui R, Suzuki M. Thin anterior uterine wall with incomplete uterine rupture in a primigravida detected by palpation and ultrasound: a case report. J Med Case Rep. 2011;5:14. doi:10.1186/1752-19475-14.

9. Gueye M, Mbaye M, Ndiaye-Gueye MD, et al. Spontaneous Uterine Rupture of an Unscarred Uterus before Labour. Case Rep Obstet Gynecol. 2012;2012:598356. doi:10.1155/2012/598356.

10. Porcu G, Courbiere B, Sakr R, Carcopino X, Gamerre M. Spontaneous rupture of a first-trimester gravid uterus in a woman exposed to diethylstilbestrol in utero. A case report. J Reprod Med. 2003;48(9):744-746.

11. Esmans A, Gerris J, Corthout E, Verdonk P, Declercq S. Placenta percreta causing rupture of an unscarred uterus at the end of the first trimester of pregnancy: case report. Hum Reprod. 2004;19(10):2401-2403. doi:10.1093/ humrep/deh421

12. Park YJ, Ryu KY, Lee JI, Park MI. Spontaneous uterine rupture in the first trimester: a case report. J Korean Med Sci. 2005;20(6):1079-1081. doi:10.3346/jkms.2005.20.6.1079.

13. Al-Zirqi I, Stray-Pedersen B, Forsen L, Daltveit AK, Vangen S. Uterine rupture: trends over 40 years. Bjog. 2016;123(5):780-787. doi:10.1111/1471-0528.13394.

14. Wang YL, Su TH. Obstetric uterine rupture of the unscarred uterus: a twenty-year clinical analysis. Gynecol Obstet Invest. 2006;62(3):131-135. doi:10.1159/000093031.

15. Singh A, Jain S. Spontaneous rupture of unscarred uterus in early pregnancy--a rare entity. Acta Obstet Gynecol Scand. 2000;79(5):431-432.

16. LeMaire WJ, Louisy C, Dalessandri K, Muschenheim F. Placenta percreta with spontaneous rupture of an unscarred uterus in the second trimester. Obstet Gynecol. 2001;98(5 Pt 2):927-929.

17. Mannini L, Sorbi F, Ghizzoni V, Masini G, Fambrini M, Noci I. Spontaneous unscarred uterine rupture at 15 weeks of pregnancy: a case report. Ochsner J. 2016;16(4):545-547.

Copyright ( 2017 The Author (s); This is an open-access article distributed under the terms of the Creative Commons Attribution License (http://creativecommons.org/licenses/by/4.0), which permits unrestricted use, distribution, and reproduction in any medium, provided the original work is properly cited. 